\title{
ANALISIS DIVERSIFIKASI PRODUK OLAHAN SALAK WEDI MENGUNAKAN METODE QUALITY FUNCTION DEPLOYMENT(QFD) DAN METODE ANALYTICAL HIERARCHY PROCESS (AHP)
}

\author{
${ }^{1}$ Moh Yusuf Dawud, ${ }^{2}$ Darsan \\ Fakultas Pertanian Universitas Bojonegoro \\ Jl. Lettu Suyitno No. 2, Kalirejo, Bojonegoro, Indonesia \\ Email : yusufdaud20.yd@gmail.com
}

\begin{abstract}
The result of this research is the objective of consumer satisfaction, almost all the attributes of Processed Coffee Beans Salak Wedi have outperformed its competitors, except for the attributes of the product packaging size which is compact and proportional, this will increase the value of sales and technical points. response as a long-term strategy, so that the value of priority contributions is increased and taken into account. Meanwhile, the value of the priority contribution of customer needs is the answer to the technical response to improvements that must be made by the Salak Wedi coffee bean home industry. There are 5 priority actions in accordance with the recommendations from the priority data processing of contribution value. The results of AHP analysis show the conclusion that the most appropriate alternative strategy for the home industry of Salak Wedi bean coffee is a product differentiation strategy with a focus on the company's competitive advantage. Attention to Marketing Costs still needs to be done for the purpose of process efficiency by removing waste and potential waste from the production process. Of course, a focus on eliminating waste will have a positive impact on improving product quality, functionality and reliability. However, Marketing Cost in this context is not part of a competitive strategy but is an improvement process for companies to increase their competitive advantage in facing current market competition.
\end{abstract}

Keywords: QFD, AHP, Salak Wedi bean coffee

\section{PENDAHULUAN}

Kopi biji salak merupakan suatu produk yang mempunyai nilai tambah tinggi. Maka dari itu perlu adanya sebuah kajian dan penelitian terkait hasil produk diversifikasi buah salak. Yang mana dalam hal ini peneliti mengunakan alat analisis QFD, supaya atribut kebutuhan konsumen kopi biji salak bisa dijadikan dua bagian, yaitu atribut pertama akan menjawab kebutuhan konsumen terkait dengan produk yang dihasilkan, penilaian tersebut berlandaskan dari bahan baku dan rasa, atribut yang kedua akan menjawab kebutuhan konsumen yang berhubungan dengan kemasan dan desain produk.

AHP adalah suatu model untuk membangun gagasan dan mendefinisikan persoalan dengan cara membuat asumsi-asumsi dan memperoleh pemecahan yang diinginkan, serta menggunakan persepsi manusia sebagai input utamanya dalam mengambil keputusan untuk mengembangkan usahatani salak Wedi sesuai prioritas kriteria dan alternatif strategi.

Tujuan dari penelitian ini adalah Bagaimana cara meningkatkan customer needs atas produk kopi biji buah salak wedi serta bagaimana strategi untuk meningkatkan animo konsumen hasil olahan salak wedi.

Berlandaskan masalah di atas, untuk mengetahui dan menganalisis fenomena diversifikasi produk salak wedi di UMKM tersebut perlu dilaksanakan penelitian yang diharapkan bisa membantu untuk mengetahui persyaratan hasil olahan buah salak yang 
diinginkan oleh konsumen, penelitian pengembangan produk buah salak menggunakan metode QFD (Quality Function Deployment) dan AHP

\section{METODE PENELITIAN}

Subyek dari penelitian ini adalah UMKM salak Wedi di Desa. Wedi Kec. Kapas Kab. Bojonegoro. Adapun studi kasus yang di ambil adalah quality function deployment (QFD) dan metode analytical hierarchy process (AHP) di Desa. Wedi.

\section{DATA DAN INSTRUMEN PENGUMPULAN DATA}

Data yang akan digunakan dalam peneilitian ini meliputi data sekunder dan data primer. Data sekunder didapatakan melalui studi pustaka yaitu penelitian-penelitian terdahulu yang terkait. Adapun data primer didapatkan melalui observasi langsung, wawancara, dan penyebaran kuesioner.

\section{TAHAPAN-TAHAPAN PENELITIAN}

Tahap penelitian ini akan menentukan rumusan masalah yang akan menjadi orientasi penelitian, tujuan, manfaat, dan ruang lingkup penelitian. Tahap selanjutnya dilakukan studi literatur berkaitan dengan penelitian untuk mengetahui perkembangan penelitian terkini. Sesuai dengan literatur studi yang penulis baca, sehingga diperoleh suatu permasalahan yang akan diangkat dalam penelitian ini. Studi literatur yang ada hubungannya dengan quality function deployment (QFD) dan metode analytical hierarchy process (AHP). Analisis data yang akan dilakukan ada beberapa tahap dalam menjalankan penelitian ini . tahapan dalam analisis yaitu:

1. Potensi UMKM salak wedi

2. Identifikasi permintaan pasar

3. Perluasan segment pasar

4. Diversifikasi produk

5. Metode QFD(Quality Function Deployment)

6. Analytical hierarchy process (AHP)

7. Produk olahan salak wedi yang sesuai keinginan konsumen

8. Pembahasan dan Penarikan Kesimpulan dan Saran

untuk itu Analytical Hierarchy Process (AHP) merupakan alat analisis yang dapat digunakan untuk menilai satu alternatif pilihan dari beberapa pilihan alternatif yang tersedia (Hefnawi \& Mohamed, 2014). 


\section{HASIL DAN PEMBAHASAN}

\section{A. Identifikasi Konsumen / User}

Untuk mempermudah pengelompokan penelitian tentang kopi biji salak wedi yang di kembangkan, maka penulis mengajukan pertanyaan tentang pengetahuan konsumen dan minat konsumen untuk membeli dan mengkonsumsi kopi biji salak wedi.

Tabel 1 Pengetahuan Dan Ketertarikan Konsumen

\begin{tabular}{|l|l|l|l|}
\hline \multicolumn{1}{|c|}{ Kriteria } & Pendapat & Jumlah & Persentase (\%) \\
\hline \multirow{2}{*}{$\begin{array}{l}\text { Pernah membeli atau mengetahui } \\
\text { produk kopi salak wedi }\end{array}$} & Sering & 7 & $22,6 \%$ \\
\cline { 2 - 4 } & Jarang & 11 & $35,5 \%$ \\
\cline { 2 - 4 } & Tidak pernah & 13 & $41,9 \%$ \\
\hline \multirow{2}{*}{ Desain kemasan yang menarik } & Bagus & 14 & $45,2 \%$ \\
\cline { 2 - 4 } & Biasa & 9 & $29 \%$ \\
\cline { 2 - 4 } & Kurang bagus & 3 & $9,7 \%$ \\
\cline { 2 - 4 } & Tidak tahu & 5 & $16,1 \%$ \\
\hline \multirow{2}{*}{ Rasa kopi yang khas biji salak } & Ya & 30 & $96,2 \%$ \\
\cline { 2 - 4 } & Tidak & 1 & $3,2 \%$ \\
\hline \multirow{2}{*}{$\begin{array}{l}\text { Mudah di jumpai di wilayah } \\
\text { bojonegoro }\end{array}$} & Ya & 10 & $30,10 \%$ \\
\cline { 2 - 4 } & Tidak & 21 & $60,51 \%$ \\
\hline
\end{tabular}

\section{B. Identifikasi Customer Needs (WHATS)}

Informasi umum dalam pelaksanaan suatu perencanaan produksi untuk mengetahui keingginan konsumen biasanya sulit untuk langsung diimplementasikan secara langsung tanpa adanya informasi keingginan dan harapan konsumen, maka perlu adanya Identifikasi Customer Needs (WHATS). Dari hasil wawancara serta menyebar kuesioner yang telah dilakukan, maka diperoleh keinginan konsumen sebagai berikut :

1. Ukuran produk yang compact dan proporsional

2. Produk Kopi Biji Salak Wedi yang mudah didapat

3. Biaya yang terjangkau

4. Rasa khas Biji salak

5. Desain Kemasan yang baik dan menarik

\section{Penentuan Tingkat Kepentingan (Importance Rating)}

Penentuan tingkat kepentingan (Importance Rating) yang di dapat dari keinginan para konsumen kopi biji salak wedi yang didapat dari hasil menyebar kuesioner kepada konsumen sebanyak 38 kuisoner. Hasil dari penyebaran kuesioner yang berjumlah 38 responden yang di jawab oleh responden sebanyak 31. Tabel 2 merupakan hasil dari tingkat kepentingan dari para konsumen kopi biji salak wedi : 
Tabel. 2 Penentuan Importance Rating

\begin{tabular}{|c|c|c|c|c|c|c|c|c|}
\hline \multirow{3}{*}{\multicolumn{2}{|c|}{ Pertanyaan }} & \multicolumn{5}{|c|}{ Penialaian } & \multirow{2}{*}{\multicolumn{2}{|c|}{$\begin{array}{c}\text { Tingkat } \\
\text { kepentingan }\end{array}$}} \\
\hline & & \multirow{2}{*}{$\begin{array}{c}\text { Tidak } \\
\text { Penting } \\
1\end{array}$} & \multirow{2}{*}{$\begin{array}{c}\text { Kurang } \\
\text { penting }\end{array}$} & \multirow{2}{*}{$\begin{array}{r}\text { Cukup } \\
\text { penting }\end{array}$} & \multirow{2}{*}{$\begin{array}{c}\text { Penting } \\
4\end{array}$} & \multirow{2}{*}{$\begin{array}{c}\text { Sangat } \\
\text { penting }\end{array}$} & & \\
\hline & & & & & & & SUM & AVG \\
\hline 1 & $\begin{array}{l}\text { Ukuran } \\
\text { kemasan } \\
\text { produk yang } \\
\text { compact dan } \\
\text { proporsional }\end{array}$ & 0 & 1 & 8 & 16 & 6 & 120 & 3,87 \\
\hline 2 & \begin{tabular}{l}
\multicolumn{2}{l}{ Produk Kopi } \\
Biji Salak \\
Wedi yang \\
mudah \\
didapat \\
\end{tabular} & 0 & 2 & 8 & 19 & 2 & 114 & 3,68 \\
\hline 3 & $\begin{array}{l}\text { Biaya yang } \\
\text { terjangkau }\end{array}$ & 0 & 2 & 11 & 15 & 5 & 122 & 3,94 \\
\hline 4 & $\begin{array}{l}\text { Rasa khas } \\
\text { Biji salak }\end{array}$ & 0 & 2 & 7 & 7 & 15 & 128 & 4,13 \\
\hline 5 & $\begin{array}{l}\text { Desain } \\
\text { Kemasan } \\
\text { yang baik } \\
\text { dan menarik }\end{array}$ & 0 & 3 & 4 & 5 & 19 & 133 & 4,29 \\
\hline
\end{tabular}

Pada Tabel diatas telah menunjukan rank untuk melakukan sebuah pengembangan Kopi biji salak wedi yang berlandaskan pada nilai Importance Rating tertinggi, nilai tertinggi berada pada desain produk yang baik dan menarik dan Rasa khas Biji salak yaitu sebesar 4,29 dan 4,13. Sedangkan nilai terendah berada pada produk kopi biji salak wedi yang mudah didapat, sebesar 3,68. Jadi prioritas dalam rank kepentingan konsumen yang perlu dikembangkan yaitu desain produk yang baik dan menarik dan Rasa khas Biji salak.

\section{Penentuan Technical Requirement}

Tahap selanjutnya yaitu untuk mengetahui keinginan dari masing - masing konsumen perlu adanya penjelasan yang khusus agar terciptanya sebuah produk yang sesuai dengan keinginan konsumen. Maka dari hasil penentuan yang didapatkan dari penilaian responden yaitu :

1. Kemasan produk yang bervariasi

2. Produk sudah mendapatkan legalitas

3. Harga bahan baku kopi biji salak wedi yang terjangkau

4. Bahaan dasar serbuk biji salak

5. Desain kemasan kopi biji salak wedi

\section{E. Penentuan Hubungan Customers Needs dengan Technical Requirement}

Langkah selanjutnya yaitu menganalisis hubungan yang berpengaruh terhadap kebutuhan konsumen kopi biji salak dengan cara penentuan hubungan yang saling berkaitan maka, dari hubungan yang saling berkaitan akan menghasilkan nilai kategori 
Moh Yusuf Dawud \& Darsan, 2020. Analisis Diversifikasi Produk Olahan Salak Wedi

Mengunakan Metode Quality Function Deployment (QFD) Dan Metode Analytical Hierarchy Process (AHP). Journal Viabel Pertanian. (2020), 14(2)42-56

kuat sedang atau lemah, dari ketiga kategori tersebut apabila di katakana kuat dari masing - masing penentuan hubungan tertentu yaitu keinginan konsumen secara langsung.

Apabila sebuah technical requirement bukan keinginan langsung para konsumen maka hubungan tersebut dikategorikan sedang atau lemah. Dari hasil kategori tersebut didapatkan perangkingan dalam tingkat pengukuran perbandingan dari satu atau beberapa obyek yang sama dengan atribut yang dibandingkan dengan obyek lainnya, Skala Ordinal merupakan tingkat pengukuran data berupa rangking data.. Untuk menggambarkan hubungan yang saling berkaitan pada nilai tersebut adalah sebagai berikut :

Nilai (9) merupakan : Hubungan Kuat

Nilai (3) merupakan : Hubungan Sedang

Nilai (1) merupakan : Hubungan Lemah

Tabel 3 Matrik Hubungan Kebutuhan Konsumen dan Kebutuhan Teknis

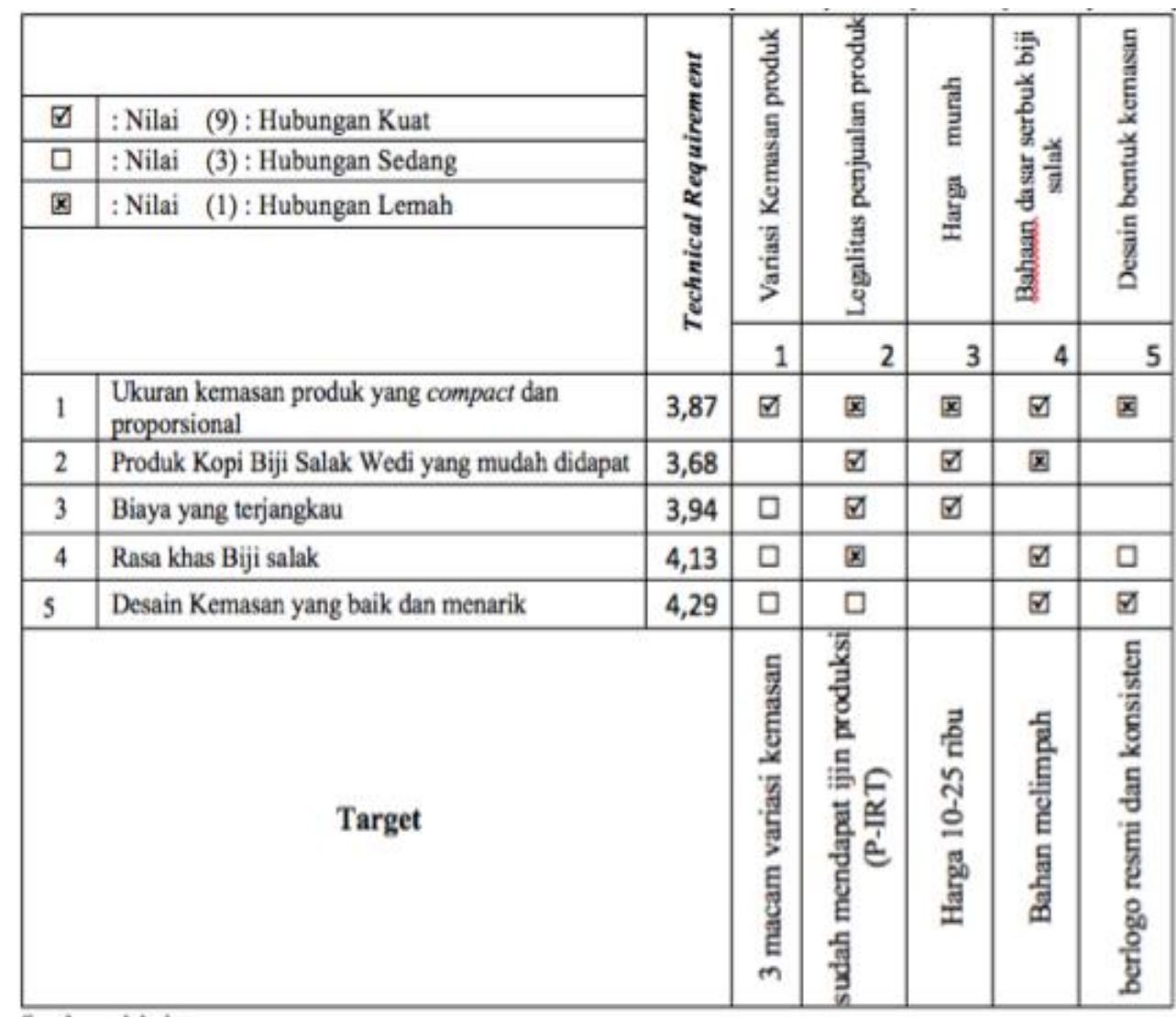

\section{F. Penentuan Matrik Korelasi}

Pada matrik ini menjelaskan hubungan antara kebutuhan teknis dari pengembang pada suatu identikasi daerah yang memungkinkan untuk dilakukan riset pengembangan produk. Berikut simbol-simbol Matrik korelasi untuk menjelaskan hubungan yang terjadi. 
Moh Yusuf Dawud \& Darsan, 2020. Analisis Diversifikasi Produk Olahan Salak Wedi

Mengunakan Metode Quality Function Deployment (QFD) Dan Metode Analytical Hierarchy Process (AHP). Journal Viabel Pertanian. (2020), 14(2)42-56

\begin{tabular}{|c|l|}
\hline 0 & $:$ Korelasi postif dan kuat \\
\hline 0 & $:$ Korelasi postif \\
\hline$X$ & $:$ Korelasi negatif \\
\hline$\#$ & $:$ Korelasi negatif dan kuat \\
\hline$\uparrow$ & $:$ Semakin dinaikkan semakin bagus \\
\hline$\downarrow$ & $:$ Semakin diturunkan semakin bagus \\
\hline ฯ & $:$ Bisa dinaikkan sampai titik tertentu \\
\hline \multirow{2}{*}{} & $:$ Bisa diturunkan sampai titik tertentu \\
\hline
\end{tabular}

Penggambaran matrik korelasi yang menunjukkan hubungan antara technical requirement adalah sebagai berikut :

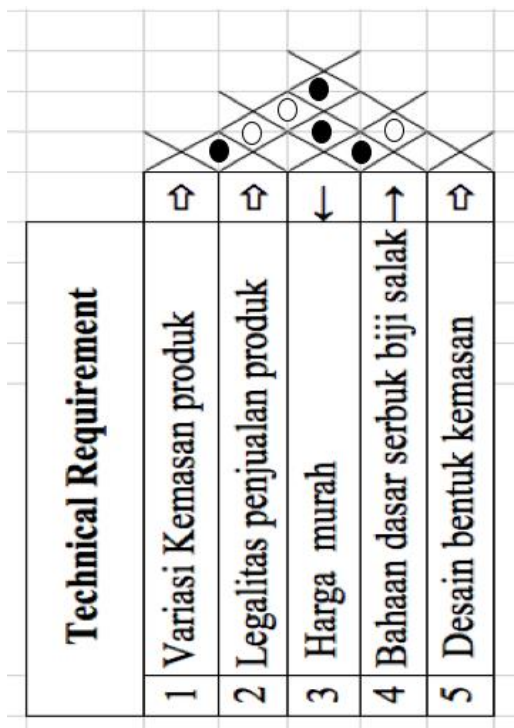

Gambar 1 Hasil Matrik Korelasi

\section{G. House Of Quality}

Untuk mengetahui identifikasi kriteria apa saja yang perlu dikembangkan oleh produsen kopi biji salak dapat dilihat pada nilai target House of Quality (HOQ). Pada gambar HOQ, kita bisa mengetahui tingkat hubungan antara atribut kebutuhan konsumen dengan karakteristik teknisnya. 


\begin{tabular}{|c|c|c|c|c|c|c|c|}
\hline & & \multirow{6}{*}{ 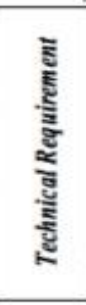 } & \multirow{5}{*}{ 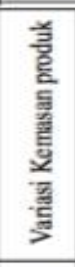 } & \multirow{5}{*}{ 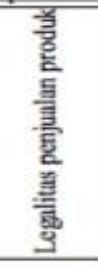 } & \multirow{5}{*}{ 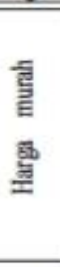 } & \multirow{5}{*}{ 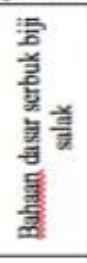 } & \multirow{5}{*}{ 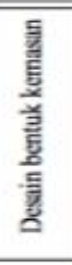 } \\
\hline$\square$ & : Nilai $\quad(9)$ : Hubungan Kuat & & & & & & \\
\hline 口 & : Nilai (3) : Hubungan Sedang & & & & & & \\
\hline \multirow[t]{3}{*}{ 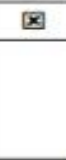 } & \multirow[t]{3}{*}{ : Nilai (1) : Hubungan Lemah } & & & & & & \\
\hline & & & & & & & \\
\hline & & & 1 & 2 & 3 & 4 & 5 \\
\hline 1 & $\begin{array}{l}\text { Ukuran kemasan produk yang compact dan } \\
\text { proporsional }\end{array}$ & 3,87 & $\square$ & $\mathbf{x}$ & $\mathbf{x}$ & 甲 & 조 \\
\hline 2 & Produk Kopi Biji Salak Wedi yang mudah didapat & 3,68 & & $\square$ & $\square$ & 지 & \\
\hline 3 & Biaya yang terjangkau & 3,94 & 口 & $\nabla$ & $\square$ & & \\
\hline 4 & Rasa khas Biji salak & 4,13 & 므 & 지 & & 口 & 므 \\
\hline 5 & Desain Kemasan yang baik dan menarik & 4,29 & 口 & 口 & & 甲 & 8 \\
\hline \multicolumn{3}{|c|}{ Target } & 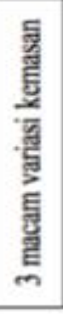 & 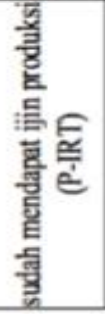 & 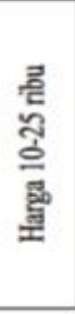 & 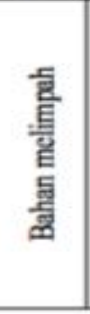 & 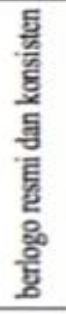 \\
\hline
\end{tabular}

\section{Gambar 2 House of Quality}

\section{H. Perencanaan produk Specification}

Untuk mengembangkan produk kopi biji perlu adanya suatu perencanaan melalui importance rating serta customer needs. Berikut hasil yang didapat dari HOQ :

a. 3 Varian kemasan produk kopi biji salak wedi dengan berbagai ukuran.

b. Legalitas produk yang terdaftar P-IRT sehingga aman untuk di konsumsi.

c. Harga terjangkau berkisar 10-25 ribu.

d. Bahan biji salak yang melimpah.

e. Berlogo resmi dan konsisten

Setelah mengetahui rincian kriteria dalam mengembangkan produk kopi biji salak wedi, langkah selanjutnya yaitu mengembangkan produk kopi biji salak mengunakan PART DEPLOYMENT Technical Requirement Target yang akan ditentukan dalam pengembangan produk. Lalu langkah selanjutnya yaitu mencari rincian kriteria dalam pembuatan wearpack, langkah selanjutnya yaitu susunan Bill Of Material (BOM).dalam penyusunan BOM yang akan dibuat berdasarkan pada data desain.

Tabel 4.Data Bill Of Materials

\begin{tabular}{|l|c|c|c|c|}
\hline \multicolumn{1}{|c|}{ ITEM } & Jumlah & Harga & satuan & total \\
\hline Kopi & 3 & 15000 & $\mathrm{Kg}$ & 45.000 \\
\hline Serbuk biji salak wedi & 1 & 2000 & $\mathrm{~kg}$ & 2000 \\
\hline Kemasan plastik & 30 & 50 & & 250000 \\
\hline LPg & 1 & & $\mathrm{pcs}$ & 65.000 \\
\hline & & & & 137.000 \\
\hline
\end{tabular}

Sumber : Olah Data 


\section{Nilai Posisi Produk Yang Dikembangkan}

Nilai posisi produk bisa didapatkan dari hasil perhitungan kuesioner tentang persepsi konsumen terhadap produk kopi biji salak wedi dan dibandingkan dengan produk kopi biji salak wedi yang pernah mahasiswa buat sebelumnya. Nilai posisi produk yang akan dikembangkan dan produk-produk lama mereka dapat dilihat dibawah ini digunakan skala 1 sampai 5 dengan keterangan sebagai berikut:
1. = Sangat Buruk
2. = Buruk
3. = Bagus
4. = Lebih Bagus
5. = Sangat Bagus

Table 5. Nilai Posisi Produk

\begin{tabular}{|c|c|c|c|c|c|c|c|c|c|c|c|c|c|}
\hline No & $\begin{array}{l}\text { Kebutuhan } \\
\text { konsumen }\end{array}$ & \multicolumn{6}{|c|}{$\begin{array}{ll}\text { Produk } & \text { Yang } \\
\text { Dikembangkan } & \end{array}$} & \multicolumn{6}{|c|}{ Produk Yang Pernah Dibuat } \\
\hline \multicolumn{2}{|c|}{ Nilai } & 1 & 2 & 3 & 4 & 5 & & 1 & 2 & 3 & 4 & 5 & \\
\hline & & \multicolumn{5}{|c|}{ Jumlah Responden } & Total & \multicolumn{5}{|c|}{ Jumlah Responden } & Total \\
\hline 1 & $\begin{array}{l}\text { Ukuran } \\
\text { kemasan } \\
\text { produk yang } \\
\text { compact dan } \\
\text { proporsional }\end{array}$ & & & 4 & 20 & 11 & 147 & 12 & 7 & 9 & 7 & & 81 \\
\hline 2 & $\begin{array}{lr}\text { Produk } & \text { Kopi } \\
\text { Biji } & \text { Salak } \\
\text { Wedi } & \text { yang } \\
\text { mudah } & \\
\text { didapat } & \end{array}$ & & 4 & 9 & 17 & 5 & 128 & 5 & 13 & 7 & 10 & & 52 \\
\hline 3 & $\begin{array}{l}\text { Biaya yang } \\
\text { terjangkau }\end{array}$ & & 1 & 3 & 24 & 7 & 142 & 4 & 10 & 10 & 11 & & 131 \\
\hline 4 & $\begin{array}{l}\text { Rasa khas } \\
\text { Biji salak } \\
\end{array}$ & & & 2 & 21 & 13 & 155 & 3 & 11 & 10 & 6 & & 115 \\
\hline 5 & $\begin{array}{l}\text { Desain } \\
\text { Kemasan } \\
\text { yang baik dan } \\
\text { menarik }\end{array}$ & & 7 & 8 & 13 & 12 & 150 & 4 & 18 & 9 & 3 & 1 & 84 \\
\hline
\end{tabular}

Sumber : Olah Data

Dari Table diatas dapat diketahui bahwa peningkatan paling besar terjadi pada peningkatan nilai Rasa khas Biji salak, Desain Kemasan yang baik dan menarik dan Ukuran kemasan produk yang compact dan proporsional. Selain pada table di atas, posisi produk yang akan dikembangkan terhadap produk lama yang pernah dibuat dapat dilihat pada gambar yang didapat dari $\mathrm{HOQ}$, dengan keterangan simbol $(\bullet)$ mewakili produk yang dikembangkan, simbol ( $\boldsymbol{\Delta})$ mewakili produk lama. 


\section{Table 6. Nilai Posisi Produk Rata-Rata}

\begin{tabular}{|c|c|c|c|c|c|c|}
\hline \multirow{2}{*}{\begin{tabular}{|l} 
No \\
Nila
\end{tabular}} & \multirow[t]{2}{*}{ Kebutuhan Mahasiwa } & \multicolumn{5}{|c|}{ Posisi Produk Versus } \\
\hline & & 1 & 2 & 3 & 4 & 5 \\
\hline & & \multicolumn{5}{|c|}{ Posisi diambil dari rata-rata } \\
\hline 1 & $\begin{array}{l}\text { Ukuran kemasan produk yang } \\
\text { compact dan proporsional }\end{array}$ & & $\angle$ & & & \\
\hline 2 & $\begin{array}{l}\text { Produk Kopi Biji Salak Wedi yang } \\
\text { mudah didapat }\end{array}$ & & 1 & & & \\
\hline 3 & Biaya yang terjangkau & & & $\Lambda$ & & \\
\hline 4 & Rasa khas Biji salak & & & $\Delta$ & & \\
\hline 5 & $\begin{array}{l}\text { Desain Kemasan yang baik dan } \\
\text { menarik }\end{array}$ & 1 & & & & \\
\hline
\end{tabular}

Sumber : Olah Data

\section{Perhitungan Identifikasi Prioritas}

Pada tahap ini terdapat beberapa perhitungan yang dapat digunakan untuk membantu proses penentuan prioritas antara lain:

Improvement Ratio : merupakan nilai penegembangan yang ingin dicapai oleh pengembang untuk memenuhi kebutuhan Konsumen. Penentuan nilai goal mengacu pada nilai posisi perbandingan produk robot pesawat tanpa awak yang akan dikembangkan dengan produk yang pernah dibuat.

Tabel 5 Improvement Ratio

\begin{tabular}{|l|c|c|c|}
\hline \multicolumn{1}{|c|}{$\begin{array}{c}\text { Kebutuhan } \\
\text { Konsumen }\end{array}$} & $\begin{array}{c}\text { Nilai Posisi } \\
\text { Produk Lama }\end{array}$ & $\begin{array}{c}\text { Nilai Posisi Produk } \\
\text { Yang Dikembangkan }\end{array}$ & $\begin{array}{c}\text { Improvement } \\
\text { Ratio }\end{array}$ \\
\hline $\begin{array}{l}\text { Ukuran kemasan } \\
\text { produk yang compact } \\
\text { dan proporsional }\end{array}$ & 2.3 & 4.2 & 1.9 \\
\hline $\begin{array}{l}\text { Produk Kopi Biji Salak } \\
\text { Wedi yang mudah } \\
\text { didapat }\end{array}$ & 2.4 & 3.7 & 1.3 \\
\hline Biaya yang terjangkau & 3.7 & 4.1 & 0.3 \\
\hline Rasa khas Biji salak & 3.3 & 4.3 & 1.0 \\
\hline $\begin{array}{l}\text { Desain Kemasan yang } \\
\text { baik dan menarik }\end{array}$ & 1.5 & 4.4 & 2.9 \\
\hline
\end{tabular}

Sumber : olah data 
Moh Yusuf Dawud \& Darsan, 2020. Analisis Diversifikasi Produk Olahan Salak Wedi

Mengunakan Metode Quality Function Deployment (QFD) Dan Metode Analytical Hierarchy Process (AHP). Journal Viabel Pertanian. (2020), 14(2)42-56

Bobot Baris : bobot baris merupakan hasil perkalian dari importance ratting dikalikan dengan improvement ratio dengan skala.

Tabel 6 Bobot Baris

\begin{tabular}{|l|c|c|c|}
\hline \multicolumn{1}{|c|}{ Kebutuhan Konsumen } & $\begin{array}{c}\text { Importance } \\
\text { ratting }\end{array}$ & $\begin{array}{c}\text { Improvement } \\
\text { Ratio }\end{array}$ & $\begin{array}{c}\text { Bobot } \\
\text { Baris }\end{array}$ \\
\hline $\begin{array}{l}\text { Ukuran kemasan produk yang compact } \\
\text { dan proporsional }\end{array}$ & 2.3 & 1.9 & $\mathbf{1 5 . 1}$ \\
\hline $\begin{array}{l}\text { Produk Kopi Biji Salak Wedi yang mudah } \\
\text { didapat }\end{array}$ & 2.4 & 1.3 & $\mathbf{6 . 2}$ \\
\hline Biaya yang terjangkau & 3.7 & 0.3 & $\mathbf{2 . 3}$ \\
\hline Rasa khas Biji salak & 3.3 & 1.0 & $\mathbf{6 . 2}$ \\
\hline Desain Kemasan yang baik dan menarik & 1.5 & 2.9 & $\mathbf{2 4 . 1}$ \\
\hline
\end{tabular}

Sumber : Olah Data

Dari hasil perhitungan bobot baris di atas dapat diketahui atribut kebutuhan Konsumen yang memiliki nilai terbesar dan mendapatkan prioritas utama dalam usulan pengembangan produk. Berikut ini urutan nilai bobot baris mulai dari nilai terbesar sampai nilai terkecil:

Tabel 7 Nilai Prioritas Pengembangan

\begin{tabular}{|c|l|c|}
\hline No. & \multicolumn{1}{|c|}{ Kebutuhan } & Prioritas \\
\hline 1 & Ukuran kemasan produk yang compact dan proporsional & 24.1 \\
\hline 2 & Produk Kopi Biji Salak Wedi yang mudah didapat & 8.1 \\
\hline 3 & Biaya yang terjangkau & 13.5 \\
\hline 4 & Rasa khas Biji salak & 9.6 \\
\hline 5 & Desain Kemasan yang baik dan menarik & 15.1 \\
\hline
\end{tabular}

\section{J. Penyusunan Alternatif Keputusan}

Dalam penyususnan alternatif keputusan atribut persaingan pasar untuk produk pembaharuan maka dapat diketahui customer needs ada 5 atribut yang berasal dari responden, dari hasil penyebaran kuesioner tersebut dari tingkat nilai kepentingan konsumen, maka dapat ditetapkan prioritas contribution value. Untuk menjawab kebutuhan dan kepentingan konsumen maka langkah usulan prioritas perbaikan produk yang dijalankan sebagai respon teknis atas kebutuhan pelanggan sehinga menjadi agenda usulan dalam pemilihan strategi pemasaran, dan perbaikan produk kopi biji salak.

Untuk menjawab tujuan kedua mengenai pengambilan keputusan dilakukan dengan cara diskusi dengan pihak produsen yang terdiri dari 3 orang dengan pengolahan data mengunakan metode AHP, dari olah data AHP melalui pair-wise comparison untuk mencari alternative strategi yang paling tepat. Proses pair-wise comparison untuk mencari alternative strategi dilakukan dengan satu persatu. Model proses pengambilan keputusan ini akan mengurai masalah multi kriteria yang kompleks menjadi hirarki yang sistematis, sederhana, dan mudah difahami.

\section{K. Matrik Perbandingan (pair-wise comparison matrix)}

Pada tahap ini matrik perbandingan berpasangan hasilnya ditabulasikan kedalam sebuah matrik bujur sangkar pada tiap kolom atribut pembanding . 
Moh Yusuf Dawud \& Darsan, 2020. Analisis Diversifikasi Produk Olahan Salak Wedi

Mengunakan Metode Quality Function Deployment (QFD) Dan Metode Analytical Hierarchy Process (AHP). Journal Viabel Pertanian. (2020), 14(2)42-56

Tabel 8. Matriks Alternatif Strategi pada Atribut Prioritas

\begin{tabular}{|c|c|c|c|c|c|c|c|c|c|}
\hline \multicolumn{5}{|c|}{ X1 Ukuran kemasan produk yang compact dan proporsional } & \multicolumn{5}{|c|}{ X2 Produk Kopi Biji Salak Wedi yang mudah didapat } \\
\hline & $\begin{array}{c}\text { marketin } \\
\text { g Cost }\end{array}$ & $\begin{array}{c}\text { Diferen } \\
\text { siasi } \\
\text { produk }\end{array}$ & $\begin{array}{l}\text { focused } \\
\text { differenti } \\
\text { ation } \\
\text { strategy }\end{array}$ & & & \multirow[t]{2}{*}{$\begin{array}{l}\text { marketi } \\
\text { ng Cost }\end{array}$} & \multirow[t]{2}{*}{$\begin{array}{c}\text { Diferen } \\
\text { siasi } \\
\text { produk }\end{array}$} & \multirow{2}{*}{$\begin{array}{c}\text { focuse } \\
\mathrm{d} \\
\text { differe } \\
\text { ntiatio } \\
\mathrm{n} \\
\text { strateg } \\
\mathrm{y}\end{array}$} & \\
\hline $\begin{array}{c}\text { Marketing } \\
\text { Cost }\end{array}$ & 1,0000 & 0,1429 & 5,0000 & & & & & & \\
\hline $\begin{array}{l}\text { Diferensia } \\
\text { si produk }\end{array}$ & 7,0000 & 1,0000 & 5,0000 & & $\begin{array}{c}\text { Marketing } \\
\text { Cost }\end{array}$ & 1,0000 & 0,2000 & 3,0000 & \\
\hline \multirow{2}{*}{$\begin{array}{c}\text { focused } \\
\text { differentia } \\
\text { tion } \\
\text { strategy }\end{array}$} & \multirow[b]{2}{*}{0,2000} & \multirow[b]{2}{*}{0,2000} & \multirow{2}{*}{\multicolumn{2}{|c|}{1,0000}} & $\begin{array}{l}\text { Diferensia } \\
\text { si produk }\end{array}$ & 5,0000 & 1,0000 & 5,0000 & \\
\hline & & & & & $\begin{array}{l}\text { focused } \\
\text { differentia }\end{array}$ & 0,3333 & 0,2000 & 1,0000 & \\
\hline sum & 13,0000 & 6,1429 & 1,4000 & Weights & $\begin{array}{l}\text { tion } \\
\text { strategy }\end{array}$ & & & & \\
\hline \multirow{2}{*}{$\begin{array}{c}\text { focused } \\
\text { differentia } \\
\text { tion } \\
\text { strategy }\end{array}$} & \multirow[b]{2}{*}{0,285714} & \multirow[b]{2}{*}{$\begin{array}{c}0,53846 \\
2\end{array}$} & \multirow[b]{2}{*}{0,232558} & \multirow[b]{2}{*}{0,228} & sum & 6,3333 & 1,4000 & 9,0000 & Weights \\
\hline & & & & & $\begin{array}{l}\text { focused } \\
\text { differentia } \\
\text { tion }\end{array}$ & $\begin{array}{c}0,28571 \\
4\end{array}$ & $\begin{array}{c}0,53846 \\
2\end{array}$ & $\begin{array}{c}0,2325 \\
58\end{array}$ & 0,211 \\
\hline \multirow{2}{*}{$\begin{array}{l}\text { Diferensia } \\
\text { si produk }\end{array}$} & \multirow{2}{*}{0,571429} & \multirow{2}{*}{$\begin{array}{c}0,30769 \\
2\end{array}$} & \multirow{2}{*}{0,697674} & \multirow{2}{*}{0,684} & strategy & & & & \\
\hline & & & & & Diferensia & 0,57142 & 0,30769 & 0,6976 & 0,686 \\
\hline $\begin{array}{c}\text { focused } \\
\text { differentia } \\
\text { tion } \\
\text { strategy }\end{array}$ & 0,142857 & $\begin{array}{c}0,15384 \\
6\end{array}$ & 0,069767 & 0,088 & $\begin{array}{c}\text { si produk } \\
\text { focused } \\
\text { differentia } \\
\text { tion } \\
\text { strategy }\end{array}$ & $\begin{array}{c}0,14285 \\
7\end{array}$ & $\begin{array}{c}0,15384 \\
6\end{array}$ & $\begin{array}{c}0,0697 \\
67\end{array}$ & 0,102 \\
\hline checksum & 1,000 & 1,000 & 1,000 & & checksum & 1,000 & 1,000 & 1,000 & \\
\hline
\end{tabular}


Copyright@UNISBA Blitar, http://ejournal.unisbablitar.ac.id/index.php/viabel

Moh Yusuf Dawud \& Darsan, 2020. Analisis Diversifikasi Produk Olahan Salak Wedi

Mengunakan Metode Quality Function Deployment (QFD) Dan Metode Analytical Hierarchy

Process (AHP). Journal Viabel Pertanian. (2020), 14(2)42-56

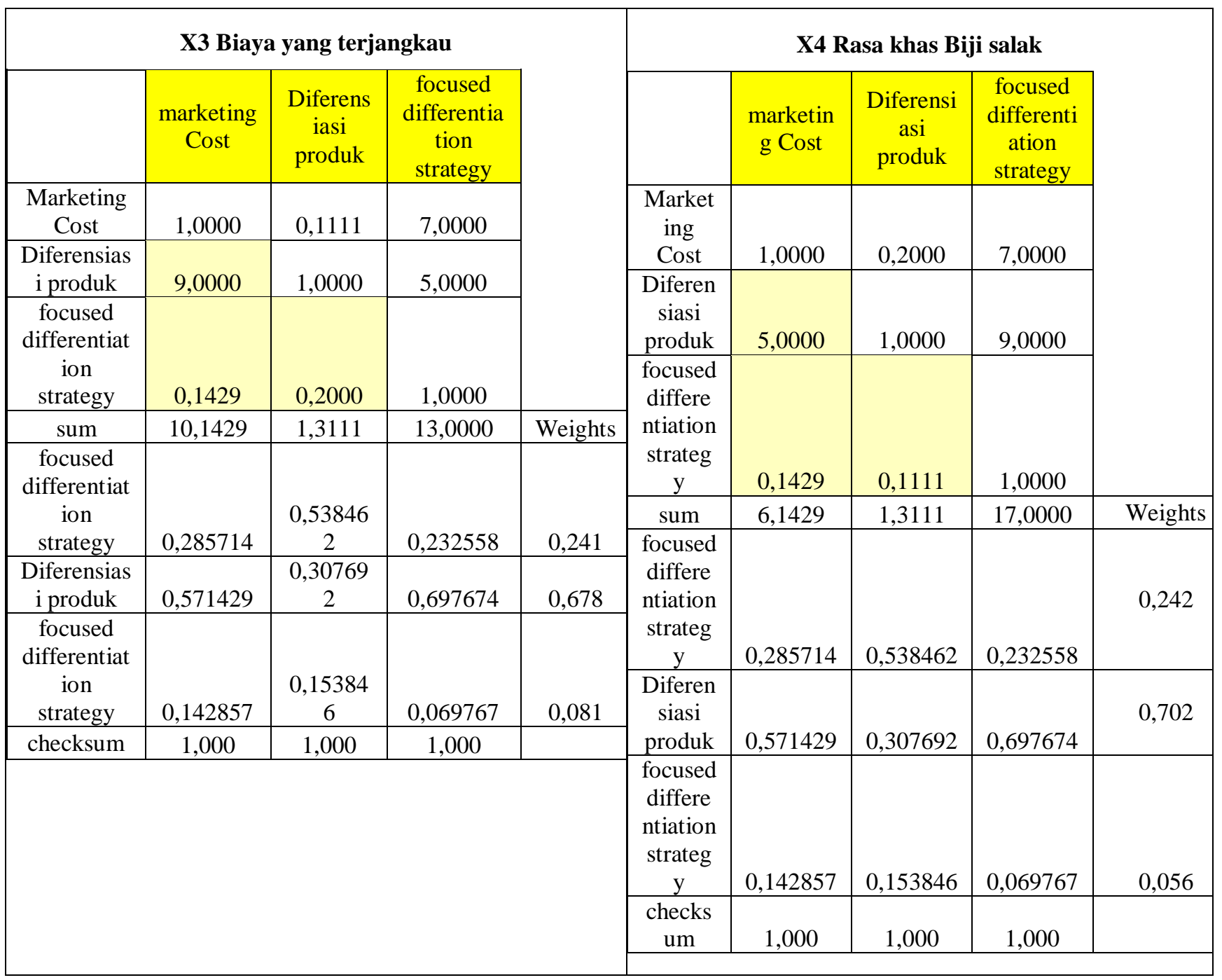




\begin{tabular}{|c|c|c|c|c|}
\hline \multicolumn{5}{|c|}{ X5 Desain Kemasan yang baik dan menarik } \\
\hline & $\begin{array}{l}\text { marketi } \\
\text { ng Cost }\end{array}$ & $\begin{array}{l}\text { Diferen } \\
\text { siasi } \\
\text { produk }\end{array}$ & $\begin{array}{l}\text { focused } \\
\text { differenti } \\
\text { ation } \\
\text { strategy }\end{array}$ & \\
\hline $\begin{array}{c}\text { Marketing } \\
\text { Cost }\end{array}$ & 1,0000 & 0,1429 & 3,0000 & \\
\hline $\begin{array}{l}\text { Diferensia } \\
\text { si produk }\end{array}$ & 7,0000 & 1,0000 & 7,0000 & \\
\hline $\begin{array}{c}\text { focused } \\
\text { differentia } \\
\text { tion } \\
\text { strategy }\end{array}$ & 0,3333 & 0,1429 & 1,0000 & \\
\hline sum & 8,3333 & 1,2857 & 11,0000 & $\begin{array}{r}\text { Weight } \\
\mathrm{s}\end{array}$ \\
\hline $\begin{array}{l}\text { focused } \\
\text { differentia } \\
\text { tion } \\
\text { strategy }\end{array}$ & $\begin{array}{r}0,28571 \\
4\end{array}$ & $\begin{array}{r}0,53846 \\
2 \\
\end{array}$ & 0,232558 & 0,168 \\
\hline $\begin{array}{l}\text { Diferensia } \\
\text { si produk }\end{array}$ & $\begin{array}{r}0,57142 \\
9 \\
\end{array}$ & $\begin{array}{r}0,30769 \\
2 \\
\end{array}$ & 0,697674 & 0,751 \\
\hline $\begin{array}{l}\text { focused } \\
\text { differentia } \\
\text { tion } \\
\text { strategy }\end{array}$ & $\begin{array}{r}0,14285 \\
7\end{array}$ & $\begin{array}{r}0,15384 \\
6\end{array}$ & 0,069767 & 0,081 \\
\hline checksum & 1,000 & 1,000 & 1,000 & \\
\hline
\end{tabular}

Tabel diatas merupakan rangkuman olah data analisis AHP untuk mencari aletrnatif strategi pada masing-masing prioritas atribut. Langkah selanjutnya penulis membuat table tabulasi data menggunakan MS. excel dan menjumlahkan total nilai pada tiap-tiap alternatif strategi, sehingga didapatkan hasil rink strategi sebagai alternative, hal ini akan dijadikan rekomendasi manajemen untuk menetapkan strategi mana yang akan digunakan dalam menghadapi persaingan pasar.

Tabel 16. Nilai Weight untuk Atribut Prioritas

\begin{tabular}{|l|c|c|c|c|c|c|}
\hline \multirow{2}{*}{ Alternatif Strategi } & \multicolumn{5}{|c|}{ Value of Weight for Priority Attributes } \\
\cline { 2 - 7 } & $\mathrm{X} 1$ & $\mathrm{X} 2$ & $\mathrm{X} 3$ & $\mathrm{X} 4$ & $\mathrm{X} 5$ & Sum \\
\hline Marketing Cost & 0,228 & 0,211 & 0,241 & 0,242 & 0,168 & 1,09 \\
\hline Diferensiasi produk & 0,684 & 0,686 & 0,678 & 0,702 & 0,751 & 3,501 \\
\hline $\begin{array}{l}\text { focused } \\
\text { differentiation } \\
\text { strategy }\end{array}$ & 0,088 & 0,102 & 0,081 & 0,056 & 0,081 & 0,408 \\
\hline
\end{tabular}

Sumber : Olah Data

Dari tiga alternatif strategi persaingan tersebut, yaitu Marketing Cost, Diferensiasi produk, dan focused differentiation strategy pada segmen pasar tertentu. Langkah selanjutnya yaitu menentuan strategi mana yang paling tepat untuk dijalankan oleh pelaku usaha kopi biji salak wedi. Dari tabel 16 terlihat bahwa nilai alternatif strategi 
Differentiation Produk jauh diatas nilai alternative yang lain dengan jumlah total weight 3,501, disusul alternative strategi Marketing Cost dengan jumlah total weight 1,09, dan terakhir strategi Focus differentiation strategy dengan jumlah total weight 0,408

\section{KESIMPULAN}

Dari hasil penggalian dan olah data dapat disimpulkan bahwa, fokus terbesar perhatian dari pelanggan adalah pada atribut Desain Kemasan yang baik dan menarik. Olahan Kopi Biji salak wedi telah mengungguli kompetitornya, kecuali pada atribut Ukuran kemasan produk yang compact dan proporsional, saat ini competitor masih lebih unggul. Home industry kopi biji salak wedi perlu lebih serius dalam memperbaikinya. Ukuran kemasan produk yang compact dan proporsional menjadi penting setelah diberi respon teknis manajemen, hal ini sesuai dengan penempatan atribut ini sebagai prioritas utama.

\section{DAFTAR PUSTAKA}

Arikunto, S. (2010). Prosedur Penelitian Suatu Pendekatan Praktek. Edisi Revisi. Jakarta: Rineka Cipta.

B\&D. (2017, Mar 07). Retrieved from http://www.bambangdjaja.com/eng/home/.

B\&D Transformer. (2017). www.bambangdjaja.com/material_training/technical.html. Retrieved from www.bambangdjaja.com.

Barlett, J., \& Kotrlik, J. (2001). Organizational research: Determining appropriate sample size in survey research. Information Technology, Learning, and Performance Journal, Vol. 19 (1), p. 43.

Bhushan, N., \& Rai, K. (2004). Strategic Decision Making, Applying the Analytic Hierarchy Process. In T. L. Saaty, Strategic Decision Making. New York: Springer, http://www.springer.com.

Cohen, L. (1995). Quality Function Deployment: How to Make QFD Work for You. Massachusetts: Addison - Wesley Longman.

David, F. (2011). Strategic Management, CONCEPTS AND CASES. New Jersey: 13th Edition, Pearson Education, Inc., Publishing as Prentice Hall.

De Felice, F., \& Petrillo, A. (2010). A multiple choice decision analysis: an integrated QFD - AHP model for the assessment of customer needs. International Journal of Engineering, Science and Technology, Vol. 2, No. 9, 2010, pp. 25-38.

EW Abryandoko (2019). Studi Penerepan Value Stream Mapping untuk Mengurangi Pemborosan pada Proses Suplay Chain (Studi Kasus di Home Industry Batu Bata Merah di Desa Ledok Kulon Kabupaten Bojonegoro). Penerbit IENACO (Industrial Engineering National Conference) 72019

Eldin, N. (2002). A Promoting Planning Tool: Quality Function Deployment. Cost Engineering, Vol 44 no 3.

Fahey, L. (1999). Competitor Analysis: Out Witting, Out Maneuvering, and Out Performing. New York City: John Wiley \& Sons, Inc. ISBN: 978-0-471-29562-4. 
Forman, E., \& Peniwati, K. (1998). Theory and Methodology Aggregating Individual Judgments and Priorities with the Analysis Hierarchy Process. European Journal of Operational Research, Vol $108: 165-169$.

Goold, M., Campbell, A., \& Alexander, M. (1994). Corporate-Level Strategy: Creating Value in the Multibusiness Company. New York: John Wiley \& Sons.

IEC. (2013). IEC 60076 an International Standard. Geneva Swizerland: International Electrotechnical commission.

Nasution, M. (2001). Manajemen Mutu Terpadu. Jakarta: Penerbit Ghalia Indonesia.

Ocampo, L., \& Clark, E. (2014). An AHP-MOLP Approach on Prioritizing Competitive Strategies Toward Sustainable Business. International of Industrial Engineering and Management (IJEM), Vol.5, No.2, pp. 95-106 ISSN 2217-2661.

Peniwati, K., \& Forman, E. (1998). Theory and Methodology Aggregating individual judgments and priorities with the Analytic Hierarchy Process. European Journal of Operational Research, 108: 165-169.

Porter, M. (1980). COMPETITIVE STRATEGY: Technique for Analyzing Industries and Competitors. New York City: The Free Press, Simon Schuster Inc., 1230 Avenue.

Porter, M. (1987, May). From Competitive Advantage to Corporate Strategy. Harvard Business Review, p. p. 65.

Saaty, T. (1993). Pengambilan Keputusan Bagi Para Pemimpin: Proses Hirarki Analitik Untuk Pengambilan Keputusan yang Kompleks. Jakarta: PT. Pustaka Binama Pressindo.

Shafer, D., \& Zhang, Z. (2012). Beginning Statistics (V.1.0). Charlotte: University of North Carolina Publishing.

Solimun, Rinaldo, A. A., \& Handoyo, S. (2017). Perencanaan dan Pengujian Kuisioner Serta Transformasi Skor Menjadi Skala Berbasis MSI, SRS, dan Rasch Model. Malang: Program Studi Statistika Jurusan Matematika, FMIPA, Univ. Brawijaya.

Suryadi, K., \& Ramdani, M. (1998). Sistem Pendukung Keputusan. Bandung: PT. Remaja Rosyda Karya.

Team FME. (2013). Porter's Five Forces, Strategy Skills. Retrieved from www.freemanagement-ebooks.com.

Wang, M., Liu, P., \& Ou, G. (2007). The Evaluation Study of Customer Satisfaction Based on Gray-AHP Method for B2C Electronic-Commerce Enterprise. Engineering Letters, 15:1, EL_15_1_24.

Wijaya, T. (2011). MANAJEMEN KUALITAS JASA, Desain Servqual, QFD, dan Kano: Disertai Contoh Aplikasi dalam Kasus Penelitian. Jakarta: PT. INDEKS.

Zeithaml, V., \& Bitner, M. (1990). Service Marketing. Ney Jersey: The McGraw-Hill Companies, Inc. 